\title{
PRINCIPAL LEADERSHIP IN DEVELOPING AL-QUR'AN LEARNING MANAGEMENT
}

\author{
Salim ${ }^{1}$, Enung Hasanah ${ }^{2}$ \\ Education Management Department, Universitas Ahmad Dahlan, Yogyakarta, Indonesia \\ Email : ahmadsalims4g@gmail.com ${ }^{1}$, enung.hasanah@mp.uad.ac.id ${ }^{2}$
}

\begin{tabular}{l|l|l} 
Received: January 2021 & Accepted: March 2021 & Published: March 2021
\end{tabular}

\begin{abstract}
:
This study aims to determine the implementation of the Principal's leadership in developing Al-Qur'an learning management that has been implemented in SMP Negeri 8 Yogyakarta City. The output of learning the Qur'an which makes the majority of students of SMP Negeri 8 Yogyakarta City able to read the Qur'an well, even some students are able to memorize the Qur'an up to 2 juz is something that is interesting to study. This research uses a qualitative approach. Participants in this study were the Principal, Islamic religious teachers and teachers of the Qur'an. The techniques used in data collection were done by using interviews, observation and documentation. Data analysis was carried out in two stages; (1) research in the field, the analysis results in this first stage are in the form of temporary conclusions obtained from the results of observations and document studies using the inductive analysis model. The conclusion data obtained in the first stage of analysis is then developed in the second stage of analysis, namely analysis after data collection. At this stage, all data were analyzed inductively by using descriptive qualitative research. The conclusion of this study shows that the Principal can develop the management of learning the Qur'an well.
\end{abstract}

Keywords: Leadership, Management, Qur'an Learning

\begin{abstract}
Abstrak:
Penelitian ini bertujuan untuk mengetahui secara mendalam implementasi kepemimpinan kepala sekolah dalam mengembangkan manajemen pembelajaran AlQur'an yang telah dilaksanakan di SMP Negeri 8 Kota Yogyakarta. Output hasil pembelajaran Al-Qur'an yang menjadikan mayoritas siswa SMP Negeri 8 Kota Yogyakarta mampu membaca Al-Qur'an dengan baik bahkan sebagian siswa mampu menghafal Al-Qur'an hingga 2 juz adalah sesuatu yang menarik untuk diteliti. Penelitian ini menggunakan pendekatan kualitatif, partisipan dalam penelitian ini adalah Kepala Sekolah, Guru Agama Islam, dan Guru Al-Qur'an. Tekhnik yang digunakan dalam pengumpulan data dilakukan dengan menggunakan interview, observasi dan dokumentasi. Analisis data dilakukan dengan dua tahap; (1) analysis in the field, dan (2) analysis after data collection. Hasil analisis pada tahap pertama ini berupa kesimpulan sementara yang diperoleh dari hasil observasi dan kajian dokumen dengan menggunakan model analisis induktif. Data simpulan yang didapat pada analisis tahap pertama selanjutnya dikembangkan pada analisis tahap kedua, yaitu analysis after data collection. Pada tahap ini, semua data dianalisis secara induktif dengan menggunakan analisis kualitatif deskriptif Kesimpulan akhir dari penelitian ini menunjukkan bahwa kepala sekolah mampu mengembangkan manajemen pembelajaran $\mathrm{Al}$ Qur'an dengan baik.
\end{abstract}

Kata Kunci: Kepemimpinan, Manajemen, Pembelajaran Al-Qur'an. 


\section{INTRODUCTION}

Learning the Qur'an is essential and very important to be taught to every Muslim student in every school (Wisaksono, Farihah, \& Ariyanti, 2018). Ideally, all students who are Muslim can read, write, and memorize the Al-Quran, but the fact is that not all Muslim students are aware of the importance of memorizing the Al-Quran that many students cannot read and remember the Al-Qur'an well. Therefore, it is necessary to develop appropriate Al-Quran education methods for students to understand and apply the moral values in the Al-Quran. Moral cultivation is essential in the student education process (Revell \& Arthur, 2007; Hasanah, 2019) so that the goals of national education can be adequately achieved.

To realize the goals of national education, various student development and self-development programs are opened to develop student's talents and interests both in intra-curricular and extra-curricular programs, with multiple activities ranging from scientific activities such as the National Science Olympiad (OSN) Development, Journalism, Youth Scientific Work (KIR) to recreational activities such as Scouting, Youth Red Cross, various sports and art clubs. Something different is seen in 8 Yogyakarta State Junior High School, one of the favorite public junior high schools in this city, to open the Al-Qur'an learning program among other student activities. This has become a distinct advantage and has even become a solution to Islamic Religious Education problems, which has many limitations for teaching Al-Quran to its students. As a predominantly Muslim nation, Muslims should make the Al-Qur'an a book that must be studied, read, memorized, understood, and practised. Memorization of Al-Qur'an at least short letters should be a science that every Muslim must learn and practice. This is because every Muslim is obliged to perform the prayers in which it is necessary to memorize the Al-Qur'an verses. As the rules of figh say:

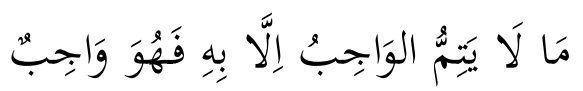

This means that something that is imperfect is an obligation. Without it, then something is obligatory (Kamrullah, 2019). The limited learning time provided for Islamic Religious Education subjects in public schools requires an effective strategy and management of Al-Qur'an learning to realize national education goals.

Effective learning (Anderson, 2020) cannot be separated from the management that is applied during the learning process because learning management is the ability of teachers to utilize their resources through activities to create and develop cooperation, so that learning is formed effectively and efficiently ( Pierson, 2001; Leontyeva, 2018). Good learning management starts from compiling learning planning, implementing learning, monitoring, carrying out assessments as an evaluation of learning, and carrying out followup on the results of the assessment.

Principal leadership is the Principal's effort to influence or mobilize all staff, teachers, students, parents, community and school stakeholders towards achieving the school's goals or vision and mission (Hasim \& Hasanah, 2020; 
Juhji, Syafe'i, \& Gunawan, 2020). The Principal leadership has a crucial role in moving the organization's wheels in building relationships between individuals to achieve organizational goals. The Principal has the responsibility to implement educational activities ( Wahyuddin, 2017; Rouf, 2019).

The school principal as a leader, has a crucial role in carrying out management functions, especially during the Covid-19 pandemic (Leontyeva, 2018). The School Development Plan and the system built to facilitate its implementation will work well if all school members have an understanding and unity of views on the vision and mission, school goals, and the willingness and ability to make it happen (Morrish \& Morrish, 2019). The failure or success of an educational institution depends on the leader's role (Baharun, Mushfi, Iq, \& Hasanah, 2020). A leader is a person who determines the direction who always guides his subordinates. The leader is also a motivator who always motivates and moves them. Besides that, he is also a supervisor who always controls directly or indirectly, so that he knows clearly about the development and progress of the program (Behlol, Yousuf, Parveen, \& Kayani, 2011).

SMP Negeri 8 Yogyakarta is one of the schools interested in learning AlQur'an for its students, especially those who are Muslim. This program can be implemented inseparably from the Principal's role, as a leader who has a vision and mission and a strong desire to realize his religious vision (Ammerman, 2014). The principal collaboration with the Islamic Religious Education teacher of SMP Negeri 8 provides strong encouragement and support to realize one of its advantages, namely excellence in the field of Islamic Religious Education, manifested in the Al-Qur'an learning program.

Based on the results of the initial survey conducted by the author, it is known that academically students who enter SMPN 8 have relatively the same abilities, but in terms of ability to read the Koran, students who come from public schools have a lower ability than students who come from Islamic schools. Students who come from schools based on the Islamic religion, such as from Muhammadiyah Schools, generally have better reading skills of the AlQur'an and some even have memorized the Al-Qur'an. So that in terms of the ability to read the Qur'an, the input of students who are Muslim at SMPN 8 has a high gap. Seeing this fact, the Principal together with the Islamic Religious Education teacher are trying to provide facilities for these two conditions, so that children who have good abilities in reading the Qur'an are facilitated by adding memorization. Meanwhile, children with low abilities receive guidance and assistance in improving recitation of the Qur'an. The aim of this program is that all Muslim students studying at SMP Negeri 8 Yogyakarta City are able to read the Al-Qur'an well and even memorize the Al-Qur'an. With this program, 95\% Muslim students of SMP Negeri 8 Yogyakarta are able to read the AlQur'an well, even some of the students are able to memorize 2 juz of Al-Qur'an. This is interesting to become a best practice that deserves to be researched and raised so that it becomes a good example and can be used as a reference for other public schools in answering the same problem. The purpose of writing this article is to determine the leadership of headmaster of SMP Negeri 8 Yogyakarta City in developing the management of Al-Qur'an learning. 


\section{RESEARCH METHODS}

This research is a qualitative research, so that the researchers are the main data collection instruments, and the data analysis is done inductively. In this study, data collection used four types of qualitative data collection strategies (Creswell, 2019), namely (1) observations, (2) interviews, and (3) documentation. Participants in this study were the Principal of the School, Islamic Religion and Al-Qur'an Teachers. Before the researcher writes the research report, the researchers check the data collected and cross-check the data obtained from interviews and observations and existing documents. By cross-checking the data, its validity can be tested and accounted for. In addition, the researchers used in-depth observation techniques and triangulation of data sources. Triangulation is defined as checking data from various sources in various ways, and at various times (Fletcher, 2015).

Data analysis was carried out in two stages: (1) analysis in the field, and (2) analysis after data collection (Bogdan, 1982). The data obtained in the first stage is in the form of field notes or fieldwork. The results of the analysis in this first stage are in the form of temporary conclusions obtained from observations and document studies using the inductive analysis model. The conclusion data obtained in the first stage of analysis is then developed in the second stage of analysis, namely analysis after data collection. At this stage, all data were analyzed inductively using descriptive qualitative analysis, namely by describing the various efforts of the Principal in developing Al-Qur'an learning management at SMP Negeri 8 Yogyakarta City.

\section{RESULTS AND DISCUSSION}

8 Yogyakarta State Junior High School is a school with an environmental perspective to form students to become religious, rational, reflective, technological, prospective, responsive and communicative human beings. This school is known as a school with many advantages, apart from being known as a school with excellent academic excellence. High school often win various competition events at the local, national and even international levels. Various achievements have been made starting in the scouting field with the receipt of the highest Garuda Scout award for the raiser group, the award in the arts as evidenced by the National Student Art Competition and Festival (FLS2N) championship, achievements in the National Student Olympiad (OSN) and many other competitions in other non-academic fields. Not satisfied with the school's academic and non-academic achievements located in Yogyakarta, the school develops its specific advantages by opening the Tahfidz Al-Qur'an program, a very rarely implemented program in public schools. In the beginning, this program was an effort to provide facilities to some students who already had a good reading of the Qur'an and had memorized the Qur'an but did not get a suitable inscription, so that among them, their memorization was lost. Seeing this, the Islamic Religious Education teacher felt a need to gather these students to get guidance whose purpose was to equip, develop, maintain the Al-Qur'an that was already owned by providing additional knowledge for those who could not read, adding to those who already had memorization, and developed those who were already good so that their 
abilities could improve better. The titillation for this idea then received full support from the Principal, who also wished to make SMP Negeri 8 Yogyakarta City have one more vision, namely excellence in Islamic Religious Education in the field of Qur'an. Based on the data obtained from the person in charge of this program, who is none other than the Islamic Religious Education teacher, the following data were found:

Table : 1 The progress of students' ability in reading the Al-Qur'an 2017-2019

\begin{tabular}{l|c|c}
\hline \multicolumn{1}{c|}{ Category } & Class 7 & Class 9 \\
\hline Can read the Koran & $19 \%$ & $100 \%$ \\
\hline Read the Qur'an with tartil & $30 \%$ & $95 \%$ \\
\hline $\begin{array}{l}\text { Memorization of Juz 30 and selected } \\
\text { letters }\end{array}$ & $51 \%$ & $80 \%$ \\
\hline Memorize Juz '30 and 29 & $0 \%$ & $10 \%$ \\
\hline
\end{tabular}

Table 1 shows that the category iqra 'is for students who have not been able to read the Qur'an. This group comprises 19\% of the total number of grade 7 Muslim students. The regular tahsin / tahfidz category. The category is for students who already have the basics of reading the Al-Qur'an but are not yet fluent; this group is $30 \%$. While the third category is Tahfidz Patas, this group is intended for students who can read the Qur'an and have their desire to memorize the Qur'an as much as $51 \%$ in the 3rd year after undergoing a learning process for 3 years; there is a significant increase. Significantly, the Iqra 'category increased from $19 \%$ to $100 \%$, the regular Tahsin and Tahfidz categories from $30 \%$ to $95 \%$ and the Tahfidz patas category from $51 \%$ to $80 \%$.

Based on the interviews with Islamic Religious Education teachers regarding the Al-Qur'an program's curriculum management process at 8 Yogyakarta State Junior High School, it refers to the learning management process, starting from planning, organizing, implementing and monitoring or controlling. In detail, the process is as follows:

Planning. The Principal of SMP Negeri 8 as the top leader in the school and the school development team decided to implement an Al-Quran learning program to help Muslim students be more competent in reading the Koran. This decision was stated in the form of a plan to develop a Quran reading program for students. Technically, the school principal delegates the Al-Quran learning management program to the PAI teacher. However, the Principal still acts in terms of making his policies. The planning process, in general, can be seen as in figure 1 below: 
Selection

Ability to read

the Al-Qur'an
Al-Qur'an reading

ability grouping
Class division of the

Tahfidz Group (Regular

group and lqra group)
Preparation of Annual

Programs, Preparation of

Semester Programs,

Preparation of Syllabus and

Figure 1 : The process of planning Al-Qur'an learning at SMPN 8 Yogyakarta

Figure 1 shows that the planning of Al-Qur'an learning begins at the beginning of the new academic year, precisely when students take the MPLS, the OSIS board assists the Islamic Religious Education teacher, sie Islamic Spirituality, who selects the ability to read Al-Qur'an for Muslim students. Based on the results of the PAI teacher selection, they arranged into three large groups, namely the iqra 'group for students who have not been able to read the Qur'an, the regular tahsin/tahfidz group for students who already have the basics of reading the Qur'an but are not yet fluent and the Tahfidz Patas group for students who are able to read the Qur'an and have their own desire to memorize the Qur'an. The Tahfidz Patas group is still regrouped into small groups consisting of $10-15$ children. The grouping is based on the speed at which students memorize the Qur'an. The Patas 1 group, for example, consists of children who have good reading skills and have a strong ability to memorize the Al-Qur'an. And so on, the patas 2 group who can read Al-Qur'an and learn skills under the patas 1 group and so on. Still in the planning process, each group is given different targets according to the level of ability of students, targets are given based on small groups consisting of 10-15 children who are taught by an Al-Qur'an teacher who has good skills in reading Al- Qur'an and enjoy teaching the Koran. The next plan is the preparation of the school calendar. Even though in writing there is no annual program, semester program and RPP of the tahfidz program, each level has a set target time. For example, the Iqra group must have completed it at the end of the semester in grade 9 so that the iqra group's output is to ensure students can read Al-Qur'an. The Tahfidz Regular group targets the completion of memorizing juz 30 in the final semester of grade 9 so that the output of this group is that children can read AlQur'an and have memorized juz 30 (Juz Amma). The Tahfidz Patas group's target in the 9th grade of the final semester is to be able to read the Qur'an well, memorize selected letters and memorize juz 30 and 29. All planning activities are carried out under the control of the Principal as the leader.

Organizing. The organizing process is carried out through various stages of activity. In general, The entire process of organizing tahfidz Al-Qur'an learning can be described as follows: 


\section{Figure 2 : The Process of Organizing Al-Qur'an Learning}

In Figure 2, it can be seen that the process of organizing Al-Qur'an learning starts from dividing tasks and arranging schedules, determining the teaching load and collaborating with student guardians. To split the Principal's duties, make a decree for the division of teaching duties and facilitate the implementation of the schedule for the tahfidz Al-Qur'an lesson schedule, which is carried out two times a week with a duration of sixty minutes per meeting. Learning is carried out at 0 (zero) hours, namely 06.15 to 07.15 hours every day. In determining the Principal's teaching load and empowering Islamic Religious Education teachers, he also cooperates with the Student Activity Unit (SAU) UIN Sunan Kalijaga Yogyakarta. Meanwhile, to smooth the implementation of the tahfidz Al-Qur'an program, the Principal invited the role of guardians of students whose sons and daughters took part in the tahfidz program by forming a community with the name of the Tahfidz Bawara committee [bawara is the name of the tahfidz committee formed by 8 Yogyakarta State Junior High School]. The purpose of establishing the Tahfidz Bawara. Management association is to support the implementation of the tahfidz program from a funding perspective. With this association, the tahfidz program at SMPN 8 Yogyakarta is getting more support from student guardians. Schools' ability to collaborate with stakeholders is one proof of the leadership ability of school principals in developing collaborations to improve school quality (Kington, 2015).

Implementation. In the process of implementing learning, it can be described as follows:

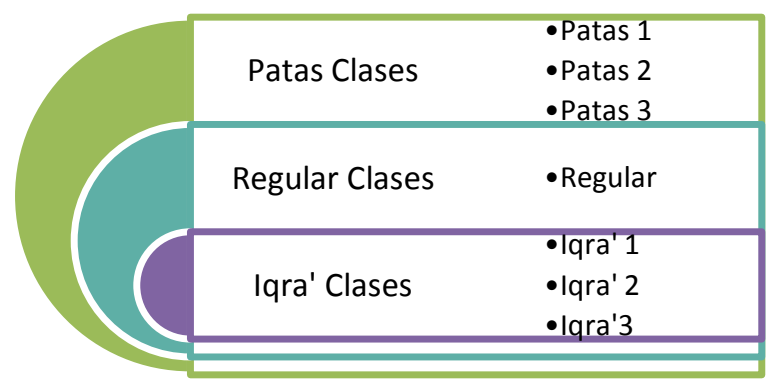

Figure 3 : The Process of Implementing Al-Qur'an Learning

Figure 3 shows that the process of implementing student learning is divided into 3 classes, namely the Tahfidz Patas class, the Regular Class and the Iqra Class'. The Tahfidz Patas class is regrouped according to the level of students' memorizing abilities into small classes consisting of 10-15 children, class Patas 1, Patas 2, Patas 3 and so on until students in this class are evenly 
divided into groups. Patas 1 class is a class that has the best memorization and reading, Patas 2 is a child who has memorization and recitation of the Qur'an slightly below patas 1 , Patas 3 is a class consisting of children who have memorized and recited the Koran below. Patas 2 and so on until students in the Patas class enter the group. Meanwhile, for the Regular class, the Al-Qur'an teacher directly teaches from the element of the Islamic Religious Education Teacher and is carried out with classical learning, due to limited space, the regular class is held in the mosque classically and is only taught by a teacher so that the regular class cannot run regularly. effective. As for the Iqra class as well as the Tahfidz Patas class, a special teacher was also invited to guide the group according to the level of the students' reading ability. Iqra 'class is divided into several small classes, namely Iqra1, Iqra2, Iqra 3, etc. An Al-Qur'an teacher teaches each class. Each group of about 8-10 students. This class is also ideal because the ratio between teacher and student is ideal, namely 1:10

In the process of implementing teacher learning in teaching it was found that the teacher did not have RPP in an administrative sense because according to the information conveyed by the Islamic religion teacher, this was not done because the tahfidz program was not included in the school curricullum and was not funded by government funds besides that because in its implementation it did not use the class as the basis for student abilities but instead used a group basis because it would make it difficult for teachers in making RPP administration. However, it does not mean that the teacher does not have any preparation for learning. In practice, the teacher begins learning by opening lessons, performing student attendance, and then performing murajaah Al-Qur'an together. After completing the muraja'ah [muraja'ah is an activity to memorize the Koran which children usually do by repeating the recitation they have memorized], each teacher varies in implementing learning strategies their level and ability. For students in the Patas 1 group independently, the students add memorization and deposit it so that they function more as facilitators and motivators. The learning strategies and methods in different groups are adjusted to the conditions of the student's ability to read the Qur'an, so that each group has a strategy. and different methods. This is because in one group there are still differences in student abilities.

Supervision. The next management process is the supervision of learning, which is an attempt to determine the achievement of learning by evaluating teaching (Deardorff, 2006). In general the supervision of learning can be described as in Figure 4 below: 


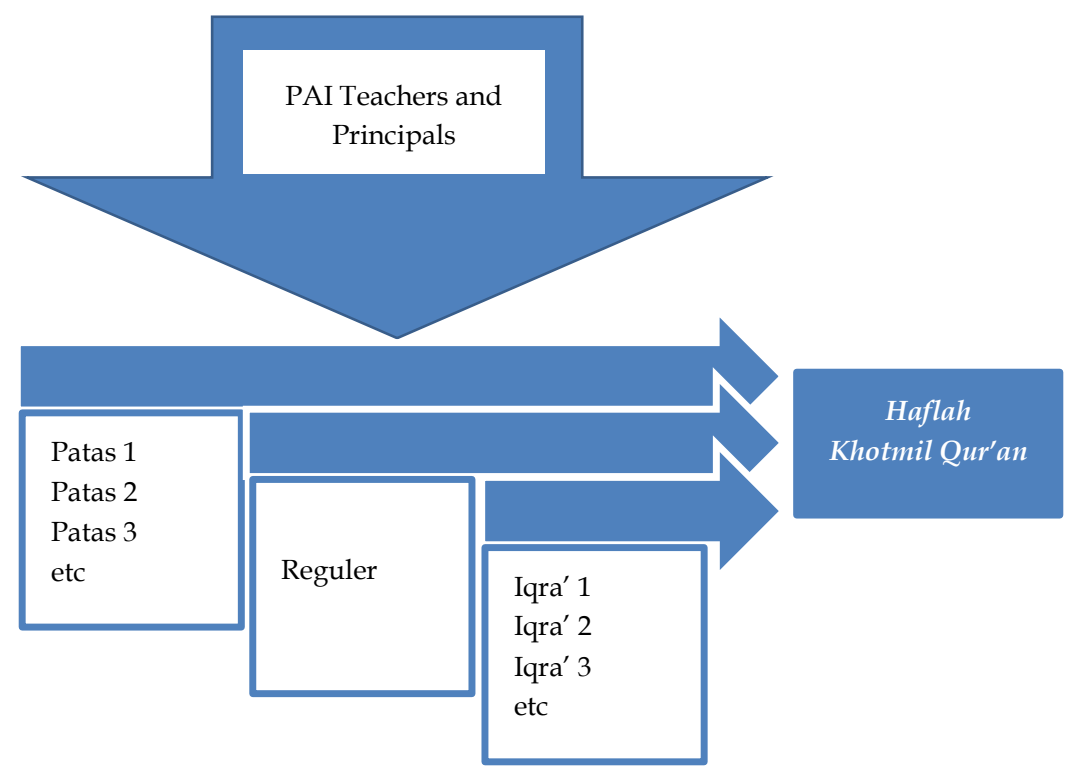

Figure 4 : Supervision of Al-Qur'an Learning

Figure 4 shows that the supervision of Al-Qur'an learning is carried out directly by the Principal assisted by the Islamic Religious Education Teacher as the Program Coordinator. In its implementation, the evaluation is carried out in the form of a written test and an oral test. In this process, the Principal together with the Tahfidz Bawara committee made a haflah khotmil Qur'an event which was held at the end of the school year. This event is intended for children who have completed the tahfidz program by first following the selection for participants who are declared to have passed the selection are allowed to take part in the haflah khotmil Qur'an. In this way the Principal automatically carries out the learning supervision process with a learning outcomes approach. One of the Principal's functions is to evaluate, so that at the end of each year the Principal together with the Islamic Religious Education teacher and the AlQur'an teachers conduct a performance evaluation of the targets that have been set at the beginning of the school year to be used as implementation guidelines for the following year.

The Principal's action to compile a plan for a management program for learning Al-Quran which begins with compiling careful planning, shows that the Principal has acted in accordance with management principles that all activities should be preceded by careful planning. The Principal applies learning based on the level of competence of students in reading the Koran so that at the beginning of entry students are selected to determine which group students are assigned to children who have read well and have memorization and strong motivation to memorize is placed in the tahfidz patas group. 1, then those who have the ability below patas 1 but want to improve their memorization are included in the patas 2 group and so on. With the group learning approach, it is hoped that students can improve their abilities maximally. Group learning is characterized by assignments, goals and rewards (Ibrahim, 2000). With this group learning, students are independent and responsible for carrying out the teacher's tasks so that the teacher is more of a 
facilitator. However, it is acknowledged by Al-Qur'an teachers that administratively they have not yet compiled an Annual Program, Semester Program and Learning Implementation Plan (RPP). Even though they do not have an Annual Program, the Semester Program and the RPP in writing each teacher have targets that must be achieved in each group.

In the process of organizing the Principal has managed and utilized existing resources in order to achieve learning objectives so that the Principal has carried out his function as a manager in learning (Kemdikbud, 2018). At this stage the Principal as the learning manager assisted by the Islamic Religious Education teacher has carried out organizing activities in preparing learning including division of tasks and scheduling, determining teaching loads and collaborating with student guardians. The Principal has also collaborated with outsiders in this case the Student Activity Unit (UKM) UIN Sunan Kalijaga Yogyakarta in helping meet Al-Qur'an teachers' needs. Thus the head acts following his duties in terms of utilizing all resources to achieve educational goals (Maria \& Sediyono, 2017).

In the implementation of learning Al-Qur'an teachers have not been guided by the lesson plans because indeed in the lesson planning, all Al-Qur'an teachers have not been required to compile lesson plans, even though the lesson plans should be the formulation of teacher guidelines in implementing learning that are used to direct the achievement of learning objectives (Blândul, 2015; Djamarah \& Zain, 2006; Laurillard, 2009). Even though the teacher has not prepared an annual program, semester program and written lesson plans, each level has determined an achievement target that must be completed within one year. So that the implementation of learning is based on predetermined targets.

In the learning evaluation process, the Principal uses two things, namely holding the Final Semester Assessment and the End of Year Assessment. At the end of the semester assessment, the assessment of tahfidz Al-Qur'an was carried out with two test models, namely an oral test which was taken from each time the memorization and reading was deposited, the second was a written test in the form of doing a written test. Meanwhile, at the end of the year a similar test was carried out, except that the Principal together with the Tahfidz Bawara association organized the haflah khotmil Qur'an event. This event is for children who have completed the tahfidz program. An assessment preceded this event. For participants who have passed the selection, they are allowed to take part in haflah khotmil Qur'an. With this event, it is automatically a form of learning assessment that is carried out at the end of the year and an award for outstanding students. This shows that the leadership role of the Principal is essential in the success of school development programs (Katz et al., 2013), including the tahfidzul Qur'an program.

\section{CONCLUSION}

Based on the results of the study, it can be concluded that in general the Principal of 8 Yogyakarta State Junior High School City has been able to develop the management of learning tahfidz Al-Qur'an well. This can be seen from the management process of planning, organizing, implementing and 
evaluating processes. Even though in the process of planning the annual program, semester programs and lesson plans have not been made by the teacher, so there is no guideline that can be used as a guide in determining student success in the learning process. But on the other hand, the Principal who PAI teachers and parents of students support is able to develop Tahfidz learning in small groups so that the effectiveness of learning is more guaranteed. As for the implementation of learning tahfidz Al-Qur'an for the Patas level has gone well, the regular level has not been able to run optimally due to the limited number of teachers and places used for learning. Meanwhile, the Iqra level can run effectively because the implementation of learning is carried out in small groups with a ratio of one teacher for 6-10 students. In the learning evaluation process, the Principal is able to develop an assessment and award at the same time in the form of a Year End Assessment in order to follow the Haflah Khatmil Qur'an. This study recommends that schools can support implementation of learning at the regular level so that it can be improved according to the ratio between the number of teachers and the number of students.

\section{REFERENCES}

Ammerman, N. T. (2014). Finding Religion in Everyday Life. Sociology of Religion, 75(2), 189-207. https://doi.org/10.1093/socrel/sru013

Anderson, T. C. (2020). Academics, Achievement Gap, and Nutritional Health: The Impact of Coronavirus on Education. Delta Kappa Gamma Bulletin, 87(1), 14-17.

Baharun, H., Mushfi, M., Iq, E., \& Hasanah, K. (2020). Leader Member Exchange dalam Membangun Komunikasi Efektif di Pondok Pesantren. El-Buhuth: Borneo Journal of Islamic Studies, 3(1), 77-89

Behlol, M. G., Yousuf, M. I., Parveen, Q., \& Kayani, M. M. (2011). Concept of Supervision and Supervisory Practices at Primary Level in Pakistan. International Education Studies, 4(4), 28-35. https://doi.org/10.5539/ies.v4n4p28

Blândul, V. C. (2015). Inovation in Education-fundamental Request of Knowledge Society. Procedia-Social and Behavioral Sciences, 180, 484-488. https:// doi.org/10.1016/j.sbspro.2015.02.148

bogdan, RS. K. B. (1982). Qualitative Research in Education. An Introduction to Theory and Methods. Boston: Allyn and Bacon.

Creswell, J. W. (2019). Research Design. Yogyakarta: Pustaka Pelajar.

Djamarah, S. B., \& Zain, A. (2006). Strategi Belajar Mengajar. Jakarta: Rineka Cipta.

Fletcher, E. (2015). Interpreting Qualitative Data. International Journal of Research $\mathcal{E}$ Method in Education, 38(4), 452-453. https://doi.org/10.1080/1743727x.2015.1066173

Hasanah, E. (2019). Perkembangan Moral Siswa Sekolah Dasar Berdasarkan Teori Kohlberg. Journal UNY, 6(2), 131-145. 
Hasim, W., \& Hasanah, E. (2020). The Role of Principal Leadership in Preventing COVID-19 Transmission at SMA Muhammadiyah 2 Karang Tengah Buay Madang Timur Indonesia. Asian Journal of Education and Social Studies, 11(1), 1-10. https://doi.org/10.9734/ajess/2020/v11i130279

Juhji, J., Syafe'i, Z., \& Gunawan, A. (2020). Kepemimpinan: Sebuah Kajian Literatur. At Tarbiyat, 3(2), 172-186.

Kamrullah, K. (2019). Ushul Fiqh dan Qawaid Al-Fiqhiyyah sebagai Metode Istinbath Pengembangan Produk Lembaga Keuangan Syariah. Tafaquh: Jurnal Hukum Ekonomi Syariah dan Ahwal Syahsiyah, 4(1), 21-35.

Katz, C., Bolton, S. L., Katz, L. Y., Isaak, C., Tilston-Jones, T., \& Sareen, J. (2013). A Systematic Review of School-based Suicide Prevention Programs. Depression and anxiety, 30(10), 1030-1045.

Kemdikbud. (2018). Peraturan Menteri Pendidikan Dan Kebudayaan Tentang Penugasan Guru Sebagai Kepala Sekolah. Jakarta: Kementrian Pendidikan dan Kebudayaan Republik Indonesia.

Kington, A. (2015). The Impact of School Leadership on Parental Engagement: A Study of Inclusion and Cohesion. International Research in Education, 1(1), 129-148. https:// doi.org/10.5296/ire.v1i1.3844

Laurillard, D. (2009). The pedagogical challenges to collaborative technologies. International Journal of Computer-Supported Collaborative Learning. 4(1), 520. https://doi.org/10.1007/s11412-008-9056-2

Leontyeva, I. A. (2018). Modern distance learning technologies in higher education: Introduction problems. Eurasia Journal of Mathematics, Science $\begin{array}{llll}\text { and Technology 14(10), Education. } & \end{array}$ https://doi.org/10.29333/ejmste/92284

Maria, E., \& Sediyono, E. (2017). Pengembangan Model Manajemen Pembelajaran Berbasis TIK di Sekolah Dasar. Kelola Jurnal Manajemen Pendidikan, 4(1), 59-71.

Morrish, I., \& Morrish, I. (2019). The School and Society. London: Routledge

Pierson, M. E. (2001). Technology integration practice as a function of pedagogical expertise. Journal of Research on Computing in Education, 33(4), 413-430. https:/ / doi.org/10.1080/08886504.2001.10782325

Revell, L., \& Arthur, J. (2007). Character Education in Schools and The Education of Teachers. Journal of Moral Education, 36(1), 79-92. https://doi.org/10.1080/03057240701194738

Rouf, A. (2019). Kepemimpinan Kepala Madrasah dalam Meningkatkan Etos Kerja Guru pada MTs Pondok Besar Roudlotul Mubtadiin Balekambang Nalumsari Jepara Tahun Pelajaran 2017/2018. Tarbawi: Jurnal Keilmuan Manajemen Pendidikan, 5(01), 97-114.

Wahyuddin, W. (2017). Headmaster Leadership and Teacher Competence in Increasing Student Achievement in School. International Education Studies, 10(3), 215-226.

Wahyuddin, W. (2017). Headmaster Leadership and Teacher Competence in Increasing Student Achievement in School. International Education Studies. https://doi.org/10.5539/ies.v10n3p215 